\title{
A Field Method for Evaluating the Potential Durability of New Resistance Sources: Application to the Leptosphaeria maculans-Brassica napus Pathosystem
}

\author{
H. Brun, S. Levivier, I. Somda, D. Ruer, M. Renard, and A. M. Chèvre
}

First, second, third, and fourth authors: Unité Mixte de Recherche INRA/ENSAR Biologie des Organismes et des Populations appliquée à la Protection des Plantes [BiO3P], INRA, Domaine de la Motte, BP 35327, F-35653 Le Rheu Cedex, France; and fifth and sixth authors: Unité Mixte de Recherches INRA/ENSAR, Amélioration des plantes et biotechnologies végétales, INRA, Domaine de la Motte, BP 35327, F-35653 Le Rheu Cedex, France. Accepted for publication 11 May 2000.

\begin{abstract}
Brun, H., Levivier, S., Somda, I., Ruer, D., Renard, M., and Chèvre, A. M. 2000. A Field method for evaluating the potential durability of new resistance sources: Application to the Leptosphaeria maculans-Brassica napus pathosystem. Phytopathology 90:961-966.

To increase the longevity of new resistance genes by avoiding a rapid change in pathogen populations, we established a new field method to determine, before the release of a resistant cultivar, whether and how rapidly the pathogen population is capable of responding to the selective pressure we impose. This method was applied to the Leptosphaeria maculans-Brassica napus pathosystem. The potential durability of two new major resistance genes introgressed into B. napus from the Brassica B genome was tested separately for each gene under field conditions for 4 years. Successive inoculations with residues of the resistant lines mixed

napus - B. juncea recombinant lines MX and MXS to inoculation of the cotyledons with a large diversity of $L$. maculans isolates. It also gave a high level of stem canker resistance in the field against natural populations of the pathogen. A similar level of resistance was obtained in the B. napus-B. nigra addition line LA4+, containing B. nigra chromosome 4 in a $B$. napus background. In the second year of the field experiment (i.e., the first in which residues from the resistant lines were included in the inoculation material), both MX and LA4+ maintained a high level of resistance. In the third and fourth years of the field experiment, the resistance of MX and MXS exposed to inoculum produced from their own residues broke down, but against fungal populations from susceptible $B$. napus or resistant B. nigra material remained effective. In contrast, LA4+ remained highly resistant to all sources of inoculum for the 4-year experiment.
\end{abstract} with susceptible contaminated plant material recovered at harvest the previous year were performed in autumn. The Jlm 1 resistance gene originating from $B$. juncea conferred complete resistance on the $B$.
Additional keywords: blackleg, Phoma lingam, population shift, resistance breakdown.
Growing concern over the sustainability of agricultural production has placed greater emphasis on crop protection strategies that provide yield stability (20). Such strategies require the management of breeding programs such that long-lasting forms of resistance are obtained and resistant cultivars are deployed to prolong the longevity of their resistance. Controlling the deployment of resistance cultivars under agricultural conditions is difficult for various reasons (25). The best approach is to create cultivars with resistance at least as durable as its utilization in commercial cultivars. Nevertheless, the principal problem is determining whether the newly selected resistance is usefully durable. This is a key question, because neither the expression of resistance (complete or partial) nor its origin provide information about durability. Johnson $(14,15)$ stated that a resistance may be durable if it remains efficient when used on large areas over several years in the presence of the disease (i.e., actual durability). Information about durability is, therefore, acquired after the release of the cultivar. Some inferences can be drawn from the characteristics of resistance. Polygenic resistance is generally more durable than monogenic resistance (24), but exceptions exist $(25,34,35)$. Consequently, resistance durability can be evaluated only by field experiments under high disease pressure and against a large-race spectrum (35). The problem is more acute for resistance genes

Corresponding author: H. Brun; E-mail address: brun@rennes.inra.fr

Publication no. P-2000-0706-01R

(C) 2000 The American Phytopathological Society never used in commercial cultivars, because virulent isolates may not be present or detectable in pathogen populations. Therefore, a method is needed to determine the durability of new resistance genes before deployment. A suitable approach under field conditions should increase the selection pressure exerted on natural pathogen populations by new resistance genes, thereby facilitating evaluation of their potential durability and of the ability of the pathogen populations to adapt. Potential durability is the ability or inability of a resistance to remain durable in conditions conducive to its breakdown for several years (diversity of fungus population, recurrent selection pressure exerted by resistance gene, favorable climatic conditions, and high inoculum pressure). High potential durability is not indicative of actual durability, however, low potential durability can indicate a risk of rapid breakdown after deployment of the resistance. Results concerning the potential durability of resistance genes currently available should be integrated into breeding strategies to create cultivars with one gene or a gene combination (specific and nonspecific) conferring the most stable resistance on the cultivars.

Leptosphaeria maculans (anamorph Phoma lingam), responsible for blackleg in crucifers, is one of the most damaging pathogens of oilseed rape (B. napus and B. campestris) in regions of the world where this crop is grown (11). The fungus survives as mycelium, pycnidia, and pseudothecia on crop residues $(9,12)$ for at least 5 years (1). Airborne ascospores discharged from pseudothecia, mainly in autumn and winter in Europe, are the most important source of primary inoculum $(9,12)$ responsible for the occurrence of severe disease outbreaks. Ascospores can spread 
over several kilometers and cause field-to-field contamination (10). Ascospores and pycnidiospores contaminate leaves, producing leaf lesions from which the fungus reaches the base of the stem by an internal systemic pathway and initiates crown canker (13). Pycnidiospores produced within pycnidia on leaf lesions constitute the secondary inoculum and contaminate neighboring plants by rain splash (4).

Currently, growing resistant cultivars is the most efficient method for limiting yield losses (28), but there is still a need to breed cultivars with higher levels of resistance. Two main types of resistance have been described in B. napus (AACC): (i) total racespecific resistances effective at the seedling stage (21), monogenic, or oligogenic (2); and (ii) partial race-nonspecific resistance only effective at the adult stage (3) and polygenic (26). New sources of resistance have been investigated and used by plant breeders to improve the resistance of oilseed rape to L. maculans. Among crucifer species, mustards possessing the $\mathrm{B}$ genome (B. juncea, AABB, brown mustard; B. nigra, BB, black mustard; and $B$. carinata, BBCC, Ethiopian mustard) display total resistance to blackleg throughout the plants life (28). Two or three genes from the $\mathrm{B}$ genome are responsible for resistance $(7,8,16,32)$. Interspecific crosses between $B$. napus and B. nigra or B. juncea were used to produce resistant oilseed rape lines $(5,6,7,27,30)$.

In this study, we report on an experiment system for assessing the potential durability of resistance genes introduced from mustards into oilseed rape. Various L. maculans populations were selected with plant residues that the fungus survives on and produce pseudothecia and pycnidia as a source of primary inoculum. We used residues from a resistant line in three successive growing seasons to increase the virulence of fungus populations. In such a system, the selection pressure exerted by the new resistance gene on L. maculans populations should increase from year to year until the resistance breaks down. Two sources of resistance from the B genome of B. juncea and B. nigra introduced into oilseed rape lines were evaluated independently in this way. The questions addressed were: (i) do L. maculans populations adapt to the new resistance; (ii) do one or both resistances break down rapidly under such conditions; and (iii) do these new resistances behave differentially to L. maculans populations with different selective histories?

\section{MATERIALS AND METHODS}

Resistant plant material from B. juncea. (Table 1). Progenies from an interspecific cross between $B$. napus and $B$. juncea were obtained by N. N. Roy (Australia, Department of Agriculture, Perth, WA). Several generations of self-pollination coupled with cytogenetic analyses and resistance tests at the cotyledon stage (INRA, Plant Breeding Station, Le Rheu, France) provided $B$.

TABLE 1. Brassica genotypes used in the study

\begin{tabular}{|c|c|c|c|}
\hline Species & Genotype & Type & $\begin{array}{l}\text { Stem canker } \\
\text { resistance }\end{array}$ \\
\hline \multirow[t]{6}{*}{ B. napus } & Shogun & Winter & Very susceptible \\
\hline & Samouraï & Winter & Intermediate \\
\hline & Falcon & Winter & Intermediate \\
\hline & Darmor & Winter & $\begin{array}{l}\text { Partial adult plant } \\
\text { resistance }\end{array}$ \\
\hline & Westar & Spring & Very susceptible \\
\hline & LA- & Winter & $\begin{array}{l}\text { Partial adult plant } \\
\text { resistance }\end{array}$ \\
\hline $\begin{array}{l}\text { B. napus-B. juncea } \\
\text { Recombinant line }\end{array}$ & MX & Spring & Resistant \\
\hline $\begin{array}{l}\text { B. napus-B. juncea } \\
\text { Recombinant line }\end{array}$ & MXS & Winter & Resistant \\
\hline $\begin{array}{l}\text { B. napus-B. nigra } \\
\text { Addition line }\end{array}$ & LA4+ & Winter & Resistant \\
\hline B. juncea & Picra & Spring & Resistant \\
\hline B. nigra & Junius & Spring & Resistant \\
\hline
\end{tabular}

napus-B. juncea recombinant lines with regular meiotic behavior and high resistance to A-Group isolates of L. maculans (5). Three random amplified polymorphic DNA (RAPD) markers were linked to the introgression, which segregated like a single gene, $J l m 1$. The recombinant line MX is a spring type. Under field conditions, MX displayed a high level of resistance toward leaf lesions and stem canker (5) but exhibited blackening at the base of the stem and root (H. Brun, unpublished data). MX was evaluated for potential durability of resistance over four growing seasons. $\mathrm{Cv}$. Westar was the spring oilseed rape susceptible control of resistant MX line.

A winter-type B. napus-B. juncea recombinant line (MXS) was obtained from a cross between MX and cv. Samouraï and from two backcrosses with cv. Samouraï and four generations of selfpollination (third year), and three backcrosses and three generations of self-pollination (fourth year). This line was used in the last two growing seasons because the breeding of this line was not sufficiently advanced for the first 2 years. Cv. Samouraï was the susceptible control of resistant MXS line. Cv. Picra (B. juncea) was used as a resistant brown mustard control.

Resistant plant material from B. nigra. (Table 1). A $B$. napus-B. nigra oilseed rape addition line (LA) possessing chromosome 4 from the B genome was obtained by interspecific crosses between B. napus (cv. Darmor) and B. nigra (cv. Junius) (6). Transmission of chromosome 4 to the progeny by self-pollination of the LA4+ line was $\approx 20 \%$. Plants with LA4+ and without LA - chromosome 4 were differentiated by a Pgi2B marker linked to the resistance gene (6). LA- line was the isogenic susceptible control of LA4+ line. B. nigra cv. Junius was a control, but few plants survived in the field trial under winter-climate conditions. The results for this cultivar are not reported.

Oilseed rape cultivars. Resistant lines were compared under field conditions with oilseed rape cultivars with various levels of resistance to stem canker: winter cvs. Darmor (high level of resistance), Falcon and Samouraï (intermediate susceptibility), and Shogun (susceptible); and spring cv. Westar (very susceptible) was used for years three and four of the experiment (Table 1). All cultivars were susceptible to leaf lesions.

Inoculum for contamination of the field trial. The lower stem and taproot of a single plant ( $\approx 20$ to $30 \mathrm{~cm}$, i.e., plant residues) were collected $\approx 2$ weeks before harvest and used as an inoculum unit. The infected residues used to contaminate the first trial originated from oilseed rape cultivars from French regions. Residues of all plots of susceptible oilseed rape and resistant lines were collected separately and mixed per genotype in June for each trial. All MX, MXS, LA4+, and oilseed rape plant residues were kept, regardless of the year and irrespective of the disease severity of stem canker observed on individual plants in June. Between harvest and autumn, genotype residues were placed separately in favorable conditions to produce sexual organs and were deposited outside on ground regularly moistened. Each year before inoculation, resistant genotype residues (MX, MXS, or LA4+) from previous trials were added to the susceptible oilseed rape inoculum to increase the inoculum pressure of isolates that may have adapted to each new resistance source. A defined mixture of resistant and susceptible residues, in a known ratio, was regularly distributed through each plot 1 month after sowing (autumn).

In the second autumn, a small number (less than 10\%) of plant residues of MX carried rare pseudothecia compared with susceptible oilseed rape cultivars for which almost $100 \%$ of plants produced numerous pseudothecia, sometimes on large plant area. The number of pseudothecia increased significantly in autumn of the third and fourth years of the experiment on MX plants (i.e., percentage of plants carrying pseudothecia and plant surface overlaid by pseudothecia reached the same level as susceptible oilseed rape residues). A few pseudothecia were seen on plants of LA4+ (i.e., 40\% of LA4+ plants carried few pseudothecia, in contrast, $80 \%$ of LA- plants carried many pseudothecia). 
Blackleg resistance tests under field conditions. The experiments were performed over a period of 4 years in Le Rheu, France, for each resistance source. Lines with $B$. nigra or $B$. juncea resistance sources were assessed in separate trials on and after the second year of the experiment. Trials were placed $\approx 10 \mathrm{~km}$ apart and were conducted each year at different locations. Results from the first year were published by Chèvre et al. $(5,6)$, and only the results of the second, third, and fourth years of the experiment are reported here. A randomized complete-block design was used with four replicates, but three replicates were scored for B. nigra resistance because plants had to be tested individually to identify LA4+ and LA- plants. For one year, the size of individual plots, sowing density, and the amount of inoculum per plot remained the same for all trials.

Second year of experiment (1993 to 1994). The second year was the first time resistant material was introduced with the inoculum. For each trial, the residues used for the inoculum in autumn 1993 was a mixture of susceptible oilseed rape cultivars (4.5 inoculum units per $\mathrm{m}^{2}$ ) and resistant plant material residues (1.5 inoculum units per $\mathrm{m}^{2}$ ) collected from the previous trial (1992 to 1993). Plot size per genotype per block was $1.5 \times 8 \mathrm{~m}$ for both trials (B. juncea and B. nigra resistances).

Third year of experiment (1994 to 1995). In autumn 1994, residues consisted of susceptible oilseed rape (1.1 inoculum units per $\mathrm{m}^{2}$ ) and resistant material residues (2.1 inoculum units per $\mathrm{m}^{2}$ ) collected from the second year of the experiment. Plot size per genotype per block was $1.5 \times 4 \mathrm{~m}$ for both trials (B. juncea and $B$. nigra resistances).

Fourth year of experiment (1995 to 1996). In autumn 1995, the same protocol was applied for residues as the third year (3.2 inoculum units per $\mathrm{m}^{2}$ ). Because the selection pressure exerted on fungus populations may have differed according to the source of resistance in previous growing seasons, the resistant lines and controls were assessed in three geographically separate trials contaminated by: (i) oilseed rape residues only (3.2 inoculum units per $\mathrm{m}^{2}$; B. napus-L. maculans populations); (ii) 2.1 inoculum units of resistant $B$. napus $-B$. juncea recombinant line residues per $\mathrm{m}^{2}(B$. juncea-L. maculans populations) plus 1.1 inoculum units of oilseed rape per $\mathrm{m}^{2}$; and (iii) 2.1 inoculum units of resistant $B$. napus-B. nigra addition line residues (B. nigra-L. maculans populations) plus 1.1 inoculum units of oilseed rape per $\mathrm{m}^{2}$. All genotypes were sown in plots of $1.5 \times 4 \mathrm{~m}$ with three replicates.

Blackleg and leaf lesion assessment. Leaf lesions were scored on all leaves of plants analyzed at least once per cropping season depending on the spread of disease. Leaf lesions were scored after identification and tagging of plants bearing chromosome 4 for $B$. nigra resistance trials. For the best representation of disease level over each plot, 3 samples of 10 consecutive plants evenly distributed were scored per plot. When possible, three replicates were scored ( 90 plants). In the second year, the number of attacked leaves per plant was scored once on both resistance trials. For the third year of the experiment, the number of leaf lesions per leaf per plant was scored on the same plants, on three dates: 22 November 1994 (30 plants per replicate with four replicates), 5 January 1995 (30 plants per genotype with one replicate), and 14 February 1995 (30 plants per replicate with three replicates) for $B$. juncea trial.

Stem canker assessment. Stem canker severity was scored $\approx 2$ weeks before maturity (June) on plants previously scored for leaf contamination. Thirty plants were scored per plot per genotype. The plants were uprooted and stem-canker scored based on the extent of internal and external symptoms at the crown of each plant. A scale was used ranging from class 1 (plants with no apparent symptoms) to class 6 (plants entirely broken down). A coefficient ( $i=0,1,3,5,7$, and 9) was assigned to each class, and the disease indice (DI) was calculated for each plot as follows: DI $=\sum_{i}\left(n_{i} \times\right.$ $i) / N$, where $n_{i}$ is the number of plants in class $i$, and $N$ is the total number of plants scored.
Statistical analysis. For leaf lesion observations, the average of the data obtained for each plot was calculated, and standard error was calculated on mean of replicates.

The stem canker DI data were surveyed by variance analysis in a randomized complete-block design including the effect of the genotypes and the blocks and the genotype $\times$ block interactions per year using STAT-ITCF software with $\alpha=0.05$. The genotypes were classified using the Student-Newman-Keuls test $(\alpha=0.05)$.

\section{RESULTS}

Leaf lesions. For fungus populations selected on plants with $B$. juncea resistance, in the second year of the experiment, the percentage of plants with leaf lesions and the number of attacked leaves per plant were lower in MX lines and cv. Picra than in cvs. Shogun, Samouraï, and Darmor (Table 2). In the third year, the percentage of disease was low on leaves of MX and MXS lines (22 November 1994), but mid-winter observations were similar to susceptible cvs. Westar and Samouraï (5 January 1995; Fig. 1). A large decrease of the disease incidence was observed for the MX line in February, probably due to the shedding of old, contaminated leaves. On cv. Picra, the disease appeared very late in winter on less than $15 \%$ of the plants with $1.5 \pm 1.7$ leaf lesions per plant (Table 2).

For fungus populations selected on plants with $B$. nigra resistance, in the third year of the experiment, more diseased plants and a larger number of attacked leaves per diseased plant were observed for the LA4+ line than previous years. (Table 3). The difference in percentage of diseased plants between the two lines (LA4+ and LA-) was smaller the third year than the second year.

Cvs. Samouraï, Darmor, and Shogun, and LA- line displayed severe leaf symptoms (Tables 2 and 3 ).

Stem canker. There was no interaction detected between genotypes and blocks for any year. The error term used was residual mean square. For all trials, variance analysis indicated high genotype differences $(P=0.0000)$ and no block effects $(0.0923 \leq P \leq 0.3695)$.

For fungus populations selected on plants with $B$. juncea resistance, in the second year of the experiment, the level of resistance of MX (DI = 1.1) was significantly higher than cv. Samouraï (DI = 4.3), and not significantly different from $B$. juncea cv. Picra $(\mathrm{DI}=0.3)$ and B. napus cv. Darmor $(\mathrm{DI}=2.1$; Table 4). However, MX showed the same degree of susceptibility (DI = $8.4)$ as cvs. Westar $(\mathrm{DI}=8.5)$ and Shogun $(\mathrm{DI}=7.4)$ in the

TABLE 2. Leaf symptoms scored on 22 March 1994 (second year) and 14 February 1995 (third year) on Brassica genotypes exposed to Leptosphaeria maculans populations selected on plants with $B$. juncea resistance

\begin{tabular}{|c|c|c|c|c|}
\hline Genotype & $\begin{array}{c}\text { Diseased } \\
\text { plants }(\%)\end{array}$ & $\begin{array}{c}\text { Attacked leaves/ } \\
\text { diseased plant }\end{array}$ & $\begin{array}{l}\text { Leaf lesions/ } \\
\text { attacked plant }\end{array}$ & $\begin{array}{c}\text { Plants } \\
\text { analyzed }\end{array}$ \\
\hline \multicolumn{5}{|l|}{$\overline{\text { Samouraï }}$} \\
\hline 1994 & $100 \pm 0.0^{\mathrm{z}}$ & $3.9 \pm 0.3$ & NT & 90 \\
\hline 1995 & $91.1 \pm 5.1$ & $3.0 \pm 1.2$ & $11.9 \pm 6.9$ & 90 \\
\hline \multicolumn{5}{|l|}{ MX } \\
\hline 1994 & $44.5 \pm 18.4$ & $1.2 \pm 0.3$ & NT & 90 \\
\hline 1995 & $48.8 \pm 6.9$ & $1.4 \pm 0.1$ & $3.4 \pm 0.8$ & 90 \\
\hline \multicolumn{5}{|l|}{ MXS } \\
\hline 1994 & NT & NT & NT & NT \\
\hline 1995 & $72.2 \pm 13.9$ & $1.6 \pm 0.1$ & $2.9 \pm 0.6$ & 90 \\
\hline \multicolumn{5}{|l|}{ Picra } \\
\hline 1994 & $11.1 \pm 8.4$ & $1.0 \pm 0.0$ & NT & 90 \\
\hline 1995 & $12.2 \pm 13.4$ & $0.8 \pm 0.7$ & $1.5 \pm 1.7$ & 90 \\
\hline \multicolumn{5}{|l|}{ Darmor } \\
\hline 1994 & $100 \pm 0.0$ & $3.6 \pm 0.1$ & NT & 30 \\
\hline 1995 & NT & NT & NT & NT \\
\hline \multicolumn{5}{|l|}{ Shogun } \\
\hline 1994 & $100 \pm 0.0$ & $2.5 \pm 0.1$ & NT & 30 \\
\hline 1995 & NT & NT & NT & NT \\
\hline
\end{tabular}

${ }^{\mathrm{z}}$ Standard error. $\mathrm{NT}=$ not tested. 
third year. The same classification was obtained in the fourth year of the experiment (Table 5). The susceptibility of MXS was intermediate between cvs. Westar and Samouraï in the third year probably because only two backcrosses were done with cv. Samouraï, but the susceptibility of this line was similar to cv. Samourai in the fourth year of the experiment (Table 5). B. juncea cv. Picra was highly resistant regardless of the year.

For fungus populations selected on plants with B. nigra resistance, throughout the experiment, LA4+ line was significantly more resistant to stem canker when exposed to B. nigra populations than cv. Darmor or LA- (Tables 4 and 5).

For the three fungus populations, in the fourth year of the experiment, the behavior of MX and MXS depended on the selected L. maculans populations. Both lines were very susceptible to fungus populations developed on B. juncea resistant lines and resistant to fungus populations developed on $B$. napus cultivars or B. nigra resistant lines (Table 5). Regardless of the selected L. maculans population, LA4+ remained stable, and cv. Picra displayed a high level of stem canker resistance (Table 5).

Regardless of the year of the experiment and the selected population, the ranking of the oilseed rape lines was not affected (Tables 4 and 5). Cvs. Westar and Shogun were the most susceptible cultivars. Conversely, cv. Darmor was the most resistant of the B. napus cultivars.

\section{DISCUSSION}

Recurrent inoculation with ascospores produced on stem residues from resistant lines increased the selection pressure exerted by resistance genes on fungus populations and enabled us to obtain different $L$. maculans populations selected on the basis of $B$. juncea (MX and MXS) and B. nigra (LA4+) resistance. Experiments performed over four successive growing seasons under field conditions demonstrated differences in the potential durability of the resistance conferred to the oilseed rape lines.

Under high inoculum pressure and against natural L. maculans populations selected on plants with $B$. juncea resistance, the stem canker resistance of the MX and MXS B. napus-B. juncea recombinant lines broke down after three growing seasons under field conditions. The duplication of this experiment over a fifth year confirmed these results ( $\mathrm{H}$. Brun, unpublished data). The Jlm 1 gene gave a selective advantage to virulent isolates that pre-existed in fungus populations, as previously shown by Somda et al. (31). These results are first to suggest that natural L. maculans populations can rapidly shift under the selection pressure exerted by a new resistance gene introduced into oilseed rape lines. Study of fungus-population dynamics over time is in progress for these trials. A low frequency of plants carrying leaf lesions was observed on the MX and MXS lines (5.8 and 2.5\%, respectively) at the first date of scoring, whereas oilseed rape cvs. Westar and Samouraï displayed more diseased plants (45 and 52.5\%, respectively) in the third year of the experiment (Fig. 1). These results are consistent with the suggestion of van der Plank (33) that specific resistance may help delay the start of an epidemic. Thus, as demonstrated by Barbetti (4), these results suggest that pycnidiospores may play a major role as secondary inoculum, strongly increasing the virulent populations in autumn and winter and thereby also increasing the level of leaf lesions and stem canker. In addition, results of the third year demonstrated that late leaf contamination in MX and MXS lines can lead to severe crown canker symptoms at harvest, in contrast to the results reported by $\mathrm{Xi}$ et al. (36).

After 4 years of similar experiments, the resistance of the $B$. napus-B. nigra addition line (LA4+) remained stable in terms of stem canker symptoms to populations selected on plants with $B$. nigra resistance. There were fewer leaf lesions on LA4+ plants than LA- plants, regardless of the year. However, the percentage of plants of the resistant line with leaf lesions increased between the second and third years of the experiment, such that it was similar for lines with and without chromosome 4 in the third year of the experiment. This may be due to increase in the proportion of virulent isolates in L. maculans populations formed on resistant plant residues. Unlike the $B$. juncea resistance gene that was introduced into a susceptible oilseed rape genetic background, the $B$. nigra resistance gene was introduced into cv. Darmor, which is partially resistant at the adult stage. Some virulent isolates infected leaves, but the defense mechanisms in such cultivars may limit the progression of the fungus through the plant to the stem

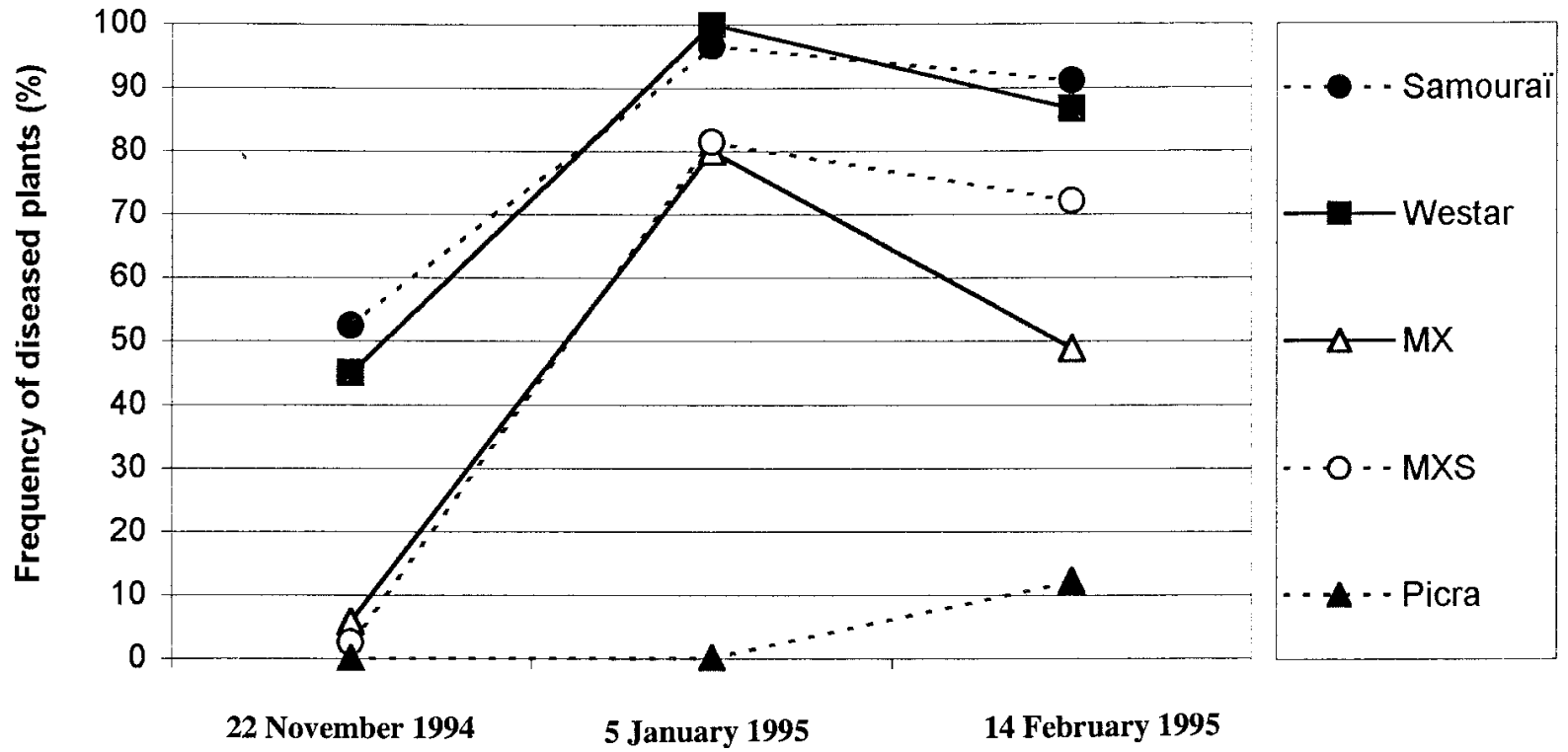

\section{Dates of assessment}

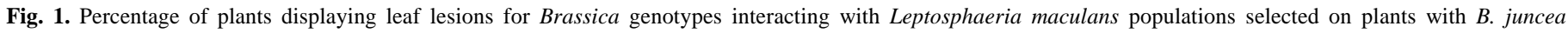
resistance in the third year of the experiment. 
base (13). These results are consistent with the model suggesting that a partially resistant genetic background may increase the durability of major resistance genes (18). Because fitness is a measure of reproductive success and survival (19), an alternative hypothesis is that virulent isolates on the LA4+ line were less fit than virulent isolates on the MX line. Moreover, because the LA line is a mixture of resistant (LA4+ $=\approx 20 \%$ ) and susceptible plants (LA- $=\approx 80 \%$ ), the plant to plant spread from leaf lesions of the virulent isolates may be slowed, as described for wheat cultivar mixtures (22). The Jlm 1 resistance gene introduced into the MX and MXS lines possessing a susceptible oilseed rape genetic background protects plants against leaf lesions. When protection against aerial contamination disappeared in the third year in MX and MXS, plants became susceptible to stem canker. In this case, there was a good correlation between leaf and stem susceptibility and resistance. In contrast, cv. Darmor, which possesses a polygenic resistance (26), displayed greater leaf lesion susceptibility in autumn and stem canker resistance at harvest than cvs. Samouraï and Shogun. Indeed, the correlation between the two symptoms depends on the resistance genes involved and the structure of the fungus populations in the field.

The behavior of the resistant lines depended on the selected fungus population. LA4+ exhibited a high level of resistance to populations selected on plants with $B$. juncea resistance. Similarly, MX and MXS were more resistant than recurrent susceptible lines to populations selected on plants with $B$. nigra resistance. Our results suggest that the two sources of resistance may exert different selection pressures on L. maculans populations and may involve different resistance genes. Our results are consistent with Chèvre et al. (5) who demonstrated that markers of these two introgressions are located on two different chromosomes of the B genome and with Roussel et al. (29) who showed that different cytological events occurred according to the origin of the gene introduced into the oilseed rape line. Studies of the structure of $L$. maculans populations selected on plants with $B$. nigra or $B$. juncea resistance are in progress to characterize further the virulence spectrum on a set carrying different resistance factors involving MXS and LA4+ lines, mustard species, and differential oilseed rape lines.

The three RAPD markers linked to the $J l m 1$ gene are also present in the genome of cv. Picra (B. juncea), and therefore, cv. Picra probably bears this gene (5). Somda et al. (31) showed that some single ascospore isolates recovered from MX residues are virulent on MX at the cotyledon stage but avirulent on B. juncea cv. Picra. Similarly, in field trials, $B$. juncea cv. Picra remained resistant to these new selected populations, although MX and MXS lines were susceptible, suggesting that more than one gene is responsible for resistance in $B$. juncea $(16,23,28)$.

Somda et al.(31) also showed that it is possible to detect variability among $L$. maculans populations for virulence on $B$. juncea resistance and that MX selected virulent pathotypes in the first year of the experiment. We demonstrated that fungus populations can evolve over a small field area until resistance breakdown. The

TABLE 3. Leaf symptoms scored on resistant line LA4+ versus susceptible line LA- exposed to Leptosphaeria maculans populations selected on plants with Brassica nigra resistance in the second (12 April 1994) and third (1 March 1995) years of the experiment

\begin{tabular}{ccccc}
\hline Genotypes & $\begin{array}{c}\text { Diseased } \\
\text { plants (\%) }\end{array}$ & $\begin{array}{c}\text { Attacked leaves/ } \\
\text { diseased plant }\end{array}$ & $\begin{array}{c}\text { Leaf lesions/ } \\
\text { attacked plant }\end{array}$ & $\begin{array}{c}\text { Plants } \\
\text { analyzed }\end{array}$ \\
\hline $\begin{array}{c}\text { LA- } \\
1994\end{array}$ & $93.0 \pm 1.1^{\mathrm{z}}$ & $2.4 \pm 0.3$ & $\mathrm{NT}$ & 288 \\
1995 & $98.9 \pm 2.0$ & $4.0 \pm 0.9$ & $14.5 \pm 4.1$ & 30 \\
LA4+ & & & & \\
1994 & $38.3 \pm 13.9$ & $1.4 \pm 0.3$ & $\mathrm{NT}$ & 85 \\
1995 & $87.7 \pm 8.4$ & $2.6 \pm 0.6$ & $4.6 \pm 0.5$ & 35 \\
\hline
\end{tabular}

${ }^{\mathrm{z}}$ Standard error. NT $=$ not tested. resistance of MX and MXS lines broke down after only 3 years of the experiment (i.e., two selection cycles of $L$. maculans populations on stem residues). This is short but consistent with the longevity of resistance (mean of 2 to 3 years after release) in cropping conditions following the modeling of rice blast resistance breakdown of resistant rice cultivars $(17,18)$. The amount of contaminated material in residues may be high under natural cropping conditions. Populations, adapted to a specific resistance gene, may be derived from previous crop residues brought back to the soil surface by plowing and in unplowed oilseed rape fields $\left(\approx 30\right.$ plants per $\left.\mathrm{m}^{2}\right)$ in the vicinity of newly sowed fields. Although our results demonstrate that the resistance of B. napus$B$. juncea recombinant lines is race-specific, they did not predict its actual durability in cropping systems. Durability depends on the presence of virulent isolates in populations, but also on fitness and interaction with local climatic conditions that might allow them to increase. Our method was applied for the first time in a major oilseed rape producing region in the center of France to evaluate the response of regional populations to the new gene $J l m 1$ introduced into various oilseed rape backgrounds. Further experiments will be performed in different regions. Currently, work is in progress to identify molecular markers to distinguish races of virulent isolates from avirulent ones and to detect them more easily in L. maculans populations. Similar experiments will follow relative frequency of virulent isolates recovered from stem canker on near isogenic susceptible and resistant lines

TABLE 4. Mean of stem canker severity (DI) on Brassica napus genotypes and resistant lines with B. juncea (MX and MXS) or B. nigra (LA4+) resistance evaluated separately on selected Leptosphaeria maculans populations in the second (1994) and third (1995) years of the experiment ${ }^{\mathrm{z}}$

\begin{tabular}{lccccc}
\hline & $\begin{array}{c}\text { L. maculans populations } \\
\text { selected on } \text { B. juncea } \\
\text { resistance }\end{array}$ & & \multicolumn{2}{c}{$\begin{array}{c}\text { L. maculans populations } \\
\text { selected on } \text { B. nigra } \\
\text { resistance }\end{array}$} \\
\cline { 2 - 3 } \cline { 5 - 6 } Genotype & 1994 & 1995 & & 1994 & 1995 \\
\hline Westar & $\mathrm{NT}$ & $8.5 \mathrm{a}$ & & $\ldots$ & $\ldots$ \\
Shogun & $6.3 \mathrm{a}$ & $7.4 \mathrm{ab}$ & & $5.9 \mathrm{a}$ & $8.3 \mathrm{a}$ \\
Samouraï & $4.3 \mathrm{~b}$ & $4.8 \mathrm{c}$ & & $3.8 \mathrm{~b}$ & $4.6 \mathrm{~b}$ \\
Falcon & $3.3 \mathrm{~b}$ & $3.6 \mathrm{~d}$ & & $2.6 \mathrm{c}$ & $4.6 \mathrm{~b}$ \\
Darmor & $2.1 \mathrm{c}$ & $2.5 \mathrm{e}$ & & $2.1 \mathrm{c}$ & $3.2 \mathrm{c}$ \\
MXS line & $\mathrm{NT}$ & $6.5 \mathrm{~b}$ & & $\ldots$ & $\ldots$ \\
MX line & $1.1 \mathrm{c}$ & $8.4 \mathrm{a}$ & & $\ldots$ & $\ldots$ \\
Picra & $0.3 \mathrm{c}$ & $2.3 \mathrm{e}$ & & $\ldots$ & $\ldots$ \\
LA- & $\ldots$ & $\ldots$ & $2.8 \mathrm{c}$ & $3.3 \mathrm{c}$ \\
LA4+ & $\ldots$ & $\ldots$ & $0.6 \mathrm{~d}$ & $1.2 \mathrm{~d}$ \\
\hline
\end{tabular}

${ }^{\mathrm{z}}$ Mean of disease indice (DI) on a scale of 0 (healthy plants) to 9 (broken down plants). NT $=$ not tested. Genotypes followed by the same letter within the same column are not significantly different $(\alpha=0.05)$.

TABLE 5. Mean of stem canker severity (DI) on Brassica napus genotypes and resistant lines with B. juncea (MX and MXS) or B. nigra (LA4+) resistance evaluated in three separate field trials in response to $B$. napus, $B$. juncea, and $B$. nigra populations of Leptosphaeria maculans in the fourth year (1996) of the experiment ${ }^{z}$

L. maculans populations selected on

\begin{tabular}{lccc}
\cline { 2 - 4 } Genotype & B. napus resistance & B. juncea resistance & B. nigra resistance \\
\hline Westar & $7.7 \mathrm{a}$ & $6.5 \mathrm{a}$ & $6.4 \mathrm{a}$ \\
Shogun & $4.6 \mathrm{~b}$ & $5.9 \mathrm{a}$ & $6.3 \mathrm{a}$ \\
Samouraï & $3.6 \mathrm{c}$ & $4.2 \mathrm{~b}$ & $4.8 \mathrm{~b}$ \\
Falcon & $2.8 \mathrm{~cd}$ & $3.3 \mathrm{~b}$ & $3.4 \mathrm{c}$ \\
Darmor & $2.2 \mathrm{de}$ & $2.2 \mathrm{c}$ & $2.6 \mathrm{~cd}$ \\
LA- line & $2.1 \mathrm{de}$ & $1.6 \mathrm{c}$ & $2.5 \mathrm{~cd}$ \\
LA4+ line & $0.6 \mathrm{f}$ & $0.4 \mathrm{~d}$ & $1.1 \mathrm{e}$ \\
MXS line & $1.4 \mathrm{e}$ & $3.6 \mathrm{~b}$ & $3.2 \mathrm{~cd}$ \\
MX line & $2.4 \mathrm{de}$ & $6.2 \mathrm{a}$ & $1.9 \mathrm{de}$ \\
Picra & $0.2 \mathrm{f}$ & $0.3 \mathrm{~d}$ & $1.0 \mathrm{e}$ \\
\hline
\end{tabular}

${ }^{\mathrm{z}}$ Mean disease indice on a scale from 0 (healthy plants) to 9 (broken down plants). Genotypes followed by the same letter are not significantly different according to Newman-Keuls homogoneous groups $(\alpha=0.05)$. 
bearing major gene and partial adult plant resistance, under different cropping systems. Work is underway at INRA, Plant Breeding Station (Le Rheu, France) to create such genotypes and to obtain $B$. napus - B. nigra recombinant lines. Analysis of epidemiological components favoring an increase in the proportion of virulent isolates within L. maculans populations would make it possible to simulate the process of resistance breakdown for various specific resistance genes. This simulation could be useful for advising plant breeders to which gene or gene combination would enable them to create cultivars with the highest resistance durability.

Our field method is reliable for evaluating and comparing the potential durability of resistance conferred to oilseed rape by new major genes before commercialization for analyzing how the pathogen population evolves over several years and for stimulating the process of resistance breakdown. It may also be useful for studying the potential durability of resistant oilseed rape material obtained by new biotechnological strategies and for other plantpathogen systems primary inoculum originating from crop residues. Knowledge of the potential durability of new resistance genes should be integrated into breeding schemes to create genotypes with more durable resistance.

\section{ACKNOWLEDGMENTS}

This work was supported by grants from AIP INRA "Etude de la coévolution des populations pathogènes et de leur hôte," CETIOM, and PROMOSOL. We thank X. Tanguy and H. Picault for technical assistance in field trials, D. Andrivon, R. Delourme, and M. Manzanares-Dauleux for reviewing the manuscript, and J. Knight for English improvement.

\section{LITERATURE CITED}

1. Alabouvette, C., and Brunin, B. 1970. Recherches sur la maladie du colza due à Leptosphaeria maculans (Desm.) Ces. Et de Not. I. Rôle des restes de culture dans la conservation et la dissémination du parasite. Ann. Phytopathol. 2:463-475.

2. Ansan-Melayah, D. 1996. Etude génétique de deux interactions racecultivar chez le pathosystème Leptosphaeria maculans/Brassica napus. Thèse. University of Paris, Orsay.

3. Ballinger, D. J., and Salisbury, P. A. 1996. Seedling and adult plant evaluation of race variability in Leptosphaeria maculans on Brassica species in Australia. Aust. J. Exp. Agric. 36:485-488.

4. Barbetti, M. J. 1976. The role of pycniospore of Leptosphaeria maculans in the spread of blackleg disease in rape. Aust. J. Exp. Agric. Anim. Husb. 16:911-914.

5. Chèvre, A. M., Barret, P., Eber, F., Dupuy, P., Brun, H., Tanguy, X., and Renard, M. 1997. Selection of stable Brassica napus-B. juncea recombinant lines resistant to Blackleg (Leptosphaeria maculans) 1: Identification of molecular markers, chromosomal and genomic origin of the introgression. Theor. Appl. Genet. 95:1104-1111.

6. Chèvre, A. M., Eber, F., This, P., Tanguy, X., Brun, H., Delseny, M., and Renard, M. 1996. Characterization of Brassica nigra chromosomes and blackleg resistance in B. napus-B. nigra addition lines. Plant Breeding 115:113-118.

7. Dixelius, C. 1999. Inheritance of the resistance to Leptosphaeria maculans of Brassica nigra and Brassica juncea in near-isogenic lines of $B$. napus. Plant Breeding 118:151-156.

8. Dixelius, C., and Wahlberg, S. 1999. Resistance to Leptosphaeria maculans is conserved in a specific region of the Brassica B genome. Theor. Appl. Genet. 99:368-372.

9. Gabrielson, R. L. 1983. Blackleg disease of crucifers caused by Leptosphaeria maculans (Phoma lingam) and its control. Seed Sci. Technol. 11:749-780.

10. Gladders, P., and Musa, T. M. 1980. Observations on epidemiology of Leptosphaeria maculans stem canker in winter oilseed rape. Plant Pathol. 29:28-37.

11. Gugel, R. K., and Petrie, G. A. 1992. History, occurrence, impact, and control of blackleg of rapeseed. Can. J. Plant Pathol. 14:36-45.
12. Hall, R. 1992. Epidemiology of blackleg of oilseed rape. Can. J. Plant Pathol. 14:46-55.

13. Hammond, K. E., and Lewis, B. G. 1987. The establishment of systemic infection in leaves of oilseed rape by Leptosphaeria maculans. Plant Pathol. 36:135-147.

14. Johnson, R. 1981. Durable resistance: Definition of genetic control and attainment in plant breeding. Phytopathology 71:567-568.

15. Johnson, R. 1984. A critical analysis of durable resistance. Annu. Rev. Phytopathol. 22:309-330.

16. Keri, M., van den Berg, C. G. J., McVetty, P. B. E., and Rimmer, S. R. 1997. Inheritance of resistance to Leptosphaeria maculans in Brassica juncea. Phytopathology 87:594-598.

17. Kiyosawa, S. 1982. Genetics and epidemiological modeling of breakdown of plant disease resistance. Annu. Rev. Phytopathol. 20:93-117.

18. Kiyosawa, S., and Shiyomi, M. 1976. Simulation of the process of breakdown of disease-resistant varieties. Jpn. J. Breed. 26:339-352.

19. Leonard, K. J. 1977. Selection pressures and plant pathogens. Ann. N.Y. Acad. Sci. 287:207-222.

20. Leung, H., Nelson, R. J., and Leach, J. E. 1993. Population structure of plant pathogenic fungi and bacteria. Adv. Plant Pathol. 10:157-205.

21. Mengistu, A., Rimmer, S. R., Koch, E., and Williams, P. H. 1991. Pathogenicity grouping of isolates of Leptosphaeria maculans on Brassica napus cultivars and their disease reaction profiles on rapid-cycling Brassicas. Plant Dis. 75:1279-1282.

22. Mundt, C. C., Brophy, L. S., and Schmitt, M. S. 1995. Disease severity and yield of pure line wheat cultivars and mixtures in the presence of eyespot, yellow rust, and their combination. Plant Pathol. 44:173-182.

23. Pang, E. C. K., and Halloran, G. M. 1996. The genetics of adult-plant blackleg (Leptosphaeria maculans) resistance from Brassica juncea in B. napus. Theor. Appl. Genet. 92:382-387.

24. Parlevliet, J. E. 1993. What is durable resistance: A general outline. Pages 23-39 in: Durability of Disease Resistance. T. H. Jacobs and J. E. Parlevliet, eds. Kluwer Academic Publishers, Dordrecht, Netherlands.

25. Parlevliet, J. E. 1995. Present problems in and aspects of breeding for disease resistance. Pages 273-287 in: Molecular Methods in Plant Pathology. R. P. Singh and U. S. Singh, eds. Lewis Publishers, Boca Raton, FL.

26. Pilet, M. L., Delourme, R., Foisset, N., and Renard, M. 1998. Identification of loci contributing to quantitative field resistance to blackleg disease, causal agent Leptosphaeria maculans (Desm.) Ces. Et de Not., in winter rapeseed (Brassica napus L.). Theor. Appl. Genet. 96:23-30.

27. Plieske, J., Struss, D., and Röbbelen, G. 1998. Inheritance of resistance derived from the B-genome of Brassica against Phoma lingam in rape seed and the development of molecular markers. Theor. Appl. Genet. 97:929-936.

28. Rimmer, S. R., and van den Berg, C. G. J. 1992. Resistance of oilseed Brassica spp. to blackleg caused by Leptosphaeria maculans. Can. J. Plant Pathol. 14:56-66.

29. Roussel, S., Nicole, M., Lopez, F., Chèvre, A. M., Renard, M., and Brun, H. 1999. Cytological expression of the resistance to Leptosphaeria maculans conferred to Brassica napus by introgressions originating from $\mathrm{B}$ genome either of $B$. juncea or $B$. nigra. Phytopathology 49:1200-1213.

30. Sacristan, M. D., and Gerdemann, M. 1986. Different behavior of Brassica juncea and Brassica carinata as sources of Phoma lingam resistance in experiments of interspecific transfer to Brassica napus. Plant Breeding 97:304-314.

31. Somda, I., Delourme, R., Renard, M., and Brun, H. 1999. Pathogenicity of Leptosphaeria maculans isolates on a Brassica napus-Brassica juncea recombinant line. Phytopathology 89:169-175.

32. Struss, D., Quiros, C. F., Plieske, J., and Röbbelen, G. 1996. Construction of Brassica B genome synteny based on chromosomes extracted from three different sources by phenotypic isozyme and molecular markers. Theor. Appl. Genet. 93:1026-1032.

33. Van der Plank, J. E. 1968. Disease Resistance in Plants. Academic Press, New York.

34. Watson, I. A. 1970. Changes in virulence and populations shifts in plant pathogens. Annu. Rev. Phytopathol. 8:209-230.

35. Wolfe, M. S. 1993. Can the strategic use of disease-resistant hosts protect their inherent durability? Pages 83-96 in: Durability of Disease Resistance. T. H. Jacobs and J. E. Parlevliet, eds. Kluwer Academic Publishers, Dordrecht, Netherlands.

36. Xi, K., Morrall, R. J., Gugel, R. K., and Verma, P. R. 1991. Latent infection in relation to the epidemiology of blackleg of spring rapeseed. Can. J. Plant Pathol. 13:321-331. 